\title{
文倉と防火対策
}

\section{1. 文倉の概観}

寝殿造などに於て、邸内の一隅に 1 棟乃至数棟に及ぶ 倉を備えていたことは衆知の通りで、大邸宅とるなると 大小幾多の倉で、1 群を形成し、所謂倉町を形成してい た。例党ば宇津保物語に、

この殿はひはだの扮とで五、廊、渡殿さるべきあてあ ての板屋どるなど有べきかぎりとて、くら季ちに御く らいと报注加り(俊落 2 )。

そみ党る様に、邸内の倉町には倉が幾棟も立並しでいた という。特に大規模でなくとも、方 1 町程度の邸宅とも なれば、邸内に数棵の御倉が設けられるのは普通で、例 えば権中納言藤原季仲の五条東洞院第は、堀河天皇の康 和 4 年 3 月 28 日飞䍜災したが、中右記飞、

家中雑物交書等一物不残、江州五倉皆以為煨燼也 とみ党、邸内に 5 㙌の倉があり、息く羅災した旨を述へ ている。季仲梳当時大宮権大夫として可成羽振りをきか せていた方だが、権中納言級でる 5 棟の倉を所有してい たのである。同じく中右記、筧治 8 年 5 月 16 日条によ ると、今夜故按察大納言藤原実季の四条坊門宅の倉が 3 棟罹災したとあるが、実季はこれより、3 年前の寛治 $\mathbf{5}$ 年 12 月 24 日に、 57 才で没して扔り、当時按察大納言 であつた。従つて位は前の季仲より上の筈だが、合数は 季仲上り少く 3 棟であつた。

上例汒上り当時の邸内には夫々幾棟かの倉が営まれた ことが分ると思うが、これらの中とは各種の倉があり、 その一にこれから述べ様とする文倉がある。文倉の現わ れる早い方で注、宇津保物語、蔵開住、

中納言見給いて驚きて、これはふみぐらならん、羔る いたいの博士の家なりけるを（上）

とみえる如く「ふみぐら」と明記されるが、この文倉は 邱内の西北隅㳊設けられていた。文倉は云う迄すなく書 籍文書等を納めて括く倉だが、当時同じく屡々でてくる 交殿も同一性質のるのたりしことは、後述するが如く、 同一建物を述べるに際し、一方では文倉といい、他方では 文殿と称していることによつてる立証されよう。文殿の ことは、源氏物語や紫式部日記、栄花物語などにる歷霬 でてくるが(1)、要するに文倉の類であり、宮中に郝ける 校書殿に当るるのであつた。斯样文交とか交殿とか明 記されない場合でも、有名な和気清磨の長子、広世が大 学別当となり、大学の南辺なる私宅内に弘文院を設け、 内外経書数干巻を蔵して私学の先鞭をつけたことは、日

\section{正会太員太静 六}

本後紀、延暦 18 年 2 月 21 日、和気朝臣清麻呂夢の条 中にみえるし、嵯线天皇が創建された有名な泠然院が、 創建以来 60 年近くを経を貞観 17 年 1 月 28 日の夜相 竾した時にも、三代実録に、

延焼含五十四宇、秘閤収蔵文書為灰燼 と記される如く、54 棟に及ぶ殿舎が痽災して、永年収 蔵されていた図籍文書が灰燼に帚したというが、その中 そは幾棟かの文倉が無論存在したことを物語つている。

平安・鎌倉時代を通じて、蔵書の多きを以て著名なる のと大江匡房の文庫がある。匡房は江家次第の著者とし て著机、後冷泉 - 後三条 - 白河 - 堀河 - 鳥羽の 5 朝任仕 之、天永 2 年 11 月、 71 才の高齢を以て夢じたというか ら、平安盛期から末期にかけて1世紀近くを過どしたこ とになるが、加觉て彼の家系が学者にして、已に累代伝 来の蔵書が多かつたので、その量の豊富なことは当代随 一にして、世に江家文庫と呼ばれ尊ばれていた。宇槐記 抄、化平 3 年 4 月 15 日条炕よる、

昔匡房卿、住二条高倉宅、建倉、其内安置書籍 と記される通り、三条高倉の期内に文倉を設け、万巻の 書を收蔵したといい、続いて曽て匡房の生存中に、前関 白藤原忠実が火災の危険を問うた所、匡房は我国がしび ない限りはこの書籍はしびず、この書籍が亡びる時は我 国が亡びる時だと答えたという。その江家文庫が、匡房 の死後 42 年後の庄平 3 年 4 月 15 日 (1153) 飞炎上乙 たので、日本が近くしびるのではないかと云つて怖れた とある。事実この江家文庫の罹災は世人に大きな衝撃を 与えたとみ穴、宇槐記抄飞、

書籍悉為灭燼、天之垶文、鳴呼亭哉 と記される他、兵範記では、樋口町尻にある江家文庫が 羅災して万巻の図書を灰にしたことは是朝之遗恨、人之

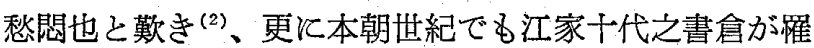

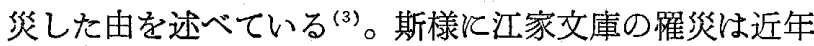
そない大損失であつたが、その位置は匡房の時の二条高 倉邸内ではなく、樋口南、西洞院東邸であつた ${ }^{(2,3)}$ 。

大江家の文庫程でなくとる、文倉の存在は平安時代を 通じてみられるが、これは鎌倉時代と入つても同様であ つた。例觉ば後堀河天皇の時だけ限つても、嘉禒 2 年 8 月 18 日飞、故宗隆卿の文庫が焼亡して和漢文書が多 く灰燼飞帰したかと思うと、それから僅か 9 日後の 8 月 26 日汇、、太政官庁の西文庫が焼亡し、累代の文書皆 灰燼に帰したという(4)。殊飞太政官庁の方は百鍊抄に、

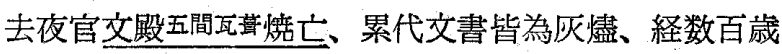


末焼之所也……末代之極欺（嘉祿 2.8.27）。

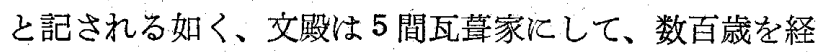
て未だ曾て罹災したことが無かつただけと慨歎の声も多 きく、末代之極といい、明月記では社稷减亡、悲而有余 と悲しんでいる。またこの場合に、同一物を百銝抄では 交殿といい、明月記では文庫と述べている様に、両者と も同意と解してよい。同じ様に、江家文庫のことを、本 朝世紀では書倉といい、兵範記では交庫と呼ぶが、これ また共文倉と同じである。

斯様《永年蒐集せる貴重な図書交書類を収蔵する文倉 が霓々䍜災して世人を悲しませてきたことは前述の通り であるが、この羅災から守る為当時としても防火手段 を全然顧みないわけですなかつた。当時として最す簡単 と考学られるのは、文倉の類を安全な場所に設けること で、有名な北条実時の創始せる金沢文庫の如きは、わぎ わざ切通しの外瀜晟して設けられたと云われ、現文 庫通じる洞門と称するすのが遭つているが、これ程の 注意をしてこそ始めて貴重な図書類を今日に伝えること が出来たのである。しかし同じ様に注意して山簏に交庫 を構えた三善善信の名越文庫が、承元 2 年 1 月に慛災し たことは吾妻鏡に、

十六日、午刻、問註所入道名越家焼亡、而於彼家後面 之山際構交庫、将軍家御文籍雑務之書並倫兼日記以下 累代文書等納置之処、悉以為厕燼、善信聞之、秋歎之 余、落源数行、心神榈然。

と記される通りで、当時問註所の要職にいた三善善信の 名越文庫が濰災して、将軍家の文籍以下累代の文書が悉 く灰煹に帰し、これを知つた善信は秋歏の挙句、落涙数 行に及んだという。

以上の 2 例は共に鎌倉幕府関係の文庫が、防火上の地 形を考虑して設けられたる例であり、殊飞実時の金沢文 庫の如きは、善信の名越交庫が折角山際に設けられたに も拘らず羅災して万巻の貴重図書類が瞬時にして失われ てゆくのを目前にみているだけに、その場所を選ぶに当 つても笽重に注意して、防火的処置を講じたのである う。しかし鐮倉附近飞招ける如く、近所飞地形上安全な 場所が見出される所は未だよいが、平安京内に和けるが 如く、平坦にして且つ人家の多い場所では、斯かる場所 の選定る出来悪いので、当然文書類を容れる建物自身を 防火的にして、火竾より守る方法が考光られる。斯くて 防火構造を見るに至つたが、その最も詳細炕して且つ具 体的に知られるのが、左大臣藤原頼長の文倉であるので 以下少しくこれを調べてみよう。

\section{2. 左大臣藤原頼長の文倉}

保元乱の首謀者として有名な左大臣藤原頼長は、関白 忠実の第 2 子として生水、幼少ょり頭絁明䀳にして父忠 実の寵を得、僅が満 15 歳にして内大臣となり、次いで 左大臣飞進んだ。学を当時の第一人者たり乙藤原信成通
憲に学び、傍ら源師頼、藤原成佐につき、僧恵暁に師事 した。己が才に走り過ぎて増長した挙句、晚年を不幸に 終光、僅か満 35 歳の一生を閉じるに至つた。事実彼は 非常な勉強家で万巻の書を読破しているが、それだけに 彼の蔵書も亦大変なるのであつた。自ら邸の一阳阳交倉 を設け、以て之等の蔵書を容れたが、この文倉を営むれ 際しては細心亘る防火的注意を試みている。その模様 は、彼の日記たる台記と詳述されるが、蓋し貴重な資料 であろう。頼長の邸宅は、宇治左大臣と呼びれる通り宇 治に設けられるが、京中にも亦設けられた。京中に特け る邸宅は台記別記、久安 4 年 8 月 9 日条中に、

大炊御門北、高倉東、方一町亭

と記される通り、大臣級としては規格通りの大いさなる 方 1 町の敷地を占めていた。文倉はこの邸中の一角没設 けられたわけで、天盖 2 年 1 月 19 日飞、大炊高倉亭の 西北隅に礎石を据光、同月 27 日飞上棟した ${ }^{(5)}$ 。文倉の 設計忹佐渡前吏伊俊で、火難無きの構、即ち防火的構汇 したといろ(5)。交倉が完成したのは 4 月 2 日で、正月の 着工より始めて足掛 4 ケ月であつた。当日は、冠直衣 つけて頼長これと臨み、春秋の緯樌をとつて先ず陽棚に 置並べ、次いで藏人式部丞滕原成佐が束帯して易詩等緯 及び河渠書掼をとつて陰棚に置並べたというが、此処に いう陽棚とは東側の棚の謂であり五重にして、陰棚とは 西側の棚の謂にして、こちらは六重であるという(6)。文 倉の規模は、4月 2 日条中に続いて、

交倉制、高一文一尺此外䂺高一尺 東西二丈三尺、南北一 文二尺一間南北有戸、四方皆推之以板、其上塗石灰、

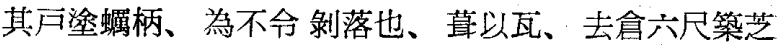
垣、広七尺、高一丈三尺、坤角有出入之道、乾角决地 令通水、芝坦外堀溝三尺、広二尺、其外栽廻竹、其外 有尋常築垣西並家外廊、東南別為倉廟 巽角南面 有戸。 とみ兄るので、可成具体的にこれを突い得られる。即ち 高さは礎石の高さ1尺、建物の高さ1丈1 尺にして、そ

\begin{tabular}{|c|c|c|c|c|c|c|}
\hline 倉 & 所 属 & 構 造 & 長さ & 広さ & 高さ & 処 \\
\hline 頼 長 & 交 倉 & 防火塗板倉 & 23.0 & 12.0 & 11.0 & 台記 \\
\hline 和家 & $\begin{array}{l}\text { 天平 } 9 \text { 年 } \\
\text { 正税 帳 }\end{array}$ & 䃏南第一甲倉 & 16.4 & 12.2 & 10.1 & 正倉 \\
\hline & $" 1$ & 西第二甲溉 & 18.0 & 16.0 & 11.0 & $" \prime$ \\
\hline & $"$ & 䧺北第伍甲倉 & 18.0 & 15.3 & 12.0 & " \\
\hline 西大= & 凍南角院 & 東桧皮甲倉 & 17.0 & 14.5 & 10.6 & 西大寺資 \\
\hline " & 正蒼 院 & 南一瓦耑甲貪 & 31.0 & 16.0 & 22.2 & " \\
\hline " & $\prime \prime$ & 二瓦甲食 & 30.0 & 16.4 & 25.5 & " \\
\hline " & " & 三瓦板 倉 & 29.3 & 16.8 & 16.3 & $" 7$ \\
\hline " & " & 四 瓦 板 倉 & 29.6 & 26.6 & 16.7 & " \\
\hline " & " & 伍 瓦 板 倉 & 20.5 & 16.0 & 12.8 & II \\
\hline " & " & 六 瓦 板 倉 & 19.6 & 15.6 & 13.0 & " \\
\hline " & " & 七桧:皮甲蒼 & 20.6 & 16.0 & 12.6 & " \\
\hline$"$ & " & 八桧皮甲倉 & 17.4 & 15.5 & 13.6 & " \\
\hline "I & "I & 九桧皮板倉 & 18.0 & 16.1 & 12.2 & $"$ \\
\hline
\end{tabular}


の平面は東西 2 丈 3 尺、南北 1 丈 2 尺であつた。約 12 坪未満となるが、この大いさが大きいのか小さいのか、 当代のものでは寸尺の明なるすのが見当らないので、奈 良時代飞持ける諸会と比較してみると表の如くになる。

即ち上表により、当時第一流寺院たる西大寺正倉院の 瓦蕞甲倉、板倉及び檜皮蕞板倉の諸倉や、和泉監正税帳 にみえる諸甲倉等に較べてみると、広さに於ては寧ろ狭 い方だが、長さに於ては比較的大きい方であり、結局そ の面積では、大体中位といろことになる。次に交倉構造 は、瓦苟板倉とあるが、注意すべきは其外装にして、板 倉の外側に石灰を塗り、南北に設けられた出入口屝の上 面には、蝺殼を塗つたというが、これは現在の漆喰仕上 に略似たるのであり、出入口戸の方は開閉に際して剝落 するのを防いで、多少特殊な工夫を試みたものである う。要するに純然たる防火構造にして、具体的に知り得 られる防火構造の最も古き例であろろ。

頼舆の防火に対する考慮は単に構造体自身を耐火的に したのみでは安心出来ず、建築物の四周にまで及んでい る。即ち前掲の如く、交倉を去ること 6 尺にして、周囲 に土㽧を築き、表面に芝を植えたが、その土䍜の幅は 13 尺、高さほ 7 尺にして、坤即ち西南隅を通路としたとい ろ。云わ法今日に於て、火楽庫等の周囲に土毗を廻らす のと同じだが、頼長はこれです満足出来ずに、土盍の四 周に深さ 3 尺、広さ 2 尺の溝を通じて防火用水とし、加 うるに竹林を以てこれを囲繞した。防火用水の方は適切 だが、竹林の方は火飞弱いので如何かと思われるが、頼 長にしてる、この位のことは無論承知の上で植えたので あろろから、別の意味があつたのか子知れない。そして この竹林の周囲汇普通の築垣を廻らしたわけだが、北面 の春日小路面する部分と、西面の高倉小路に面する部 分の 2 面は、郎自身の築垣を以て其儘これを当て、東・ 南両面の築垣を新に文倉の為に新造した。

以上で分る如く、交倉を守る為に、先ず板倉の文倉自 体の屋蓋並に䭚体、屝等を防火構造とした上、文倉の周 囲飞、土畦・防火用水・竹林 - 築垣の順飞徒つて、四重

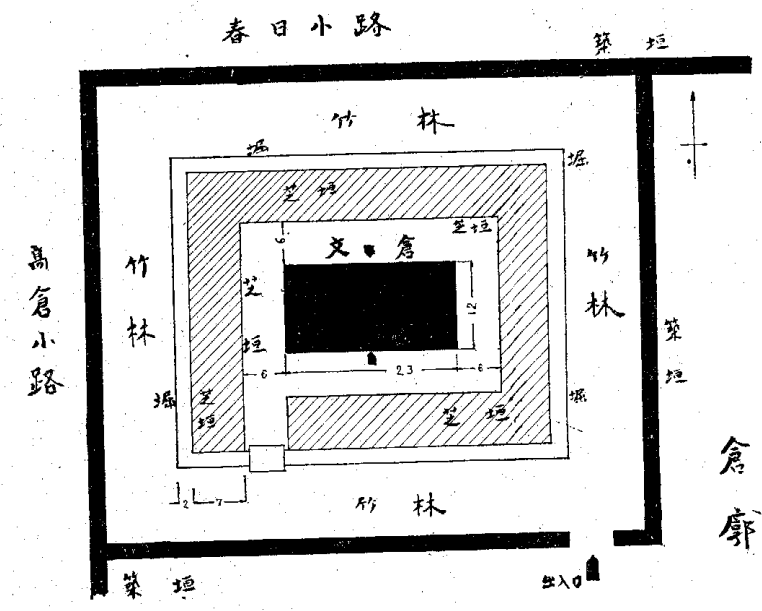

第 1 図左大臣藤原頼長邸文倉配置困
飞亘る防火対策を講じ、以て文會の万然を期したわけで ある。恐らくこれが、頼長としてと云うよりは、当時と しては出来る限りの耐火施設であつたろうから、これと より、当時に怙ける防火対策の程度を䂓うことが出来よ う。試みに、これらの状態を一応まとめて図示せるるの が第 1 図である。

文倉に限らず、一般に諸弇を営むに当つて、先ず第一 に注意するのは、収納物が良好飞保存されることである ろが、その為には現正倉院校倉にみられる如く、床を高 くして湿気や外敵から守る方法が適切であつた。所がこ の木造高床式では、品物の保存には良好であつても、防 火上は少しも考慮されていないので、次に考学られたの が防火対策であり、その代表的例が頼長の文殿にみられ るが、これ恰子今日に和ける太造モルタル塗簡易耐火 構造と本質的には何等異なる所がない。

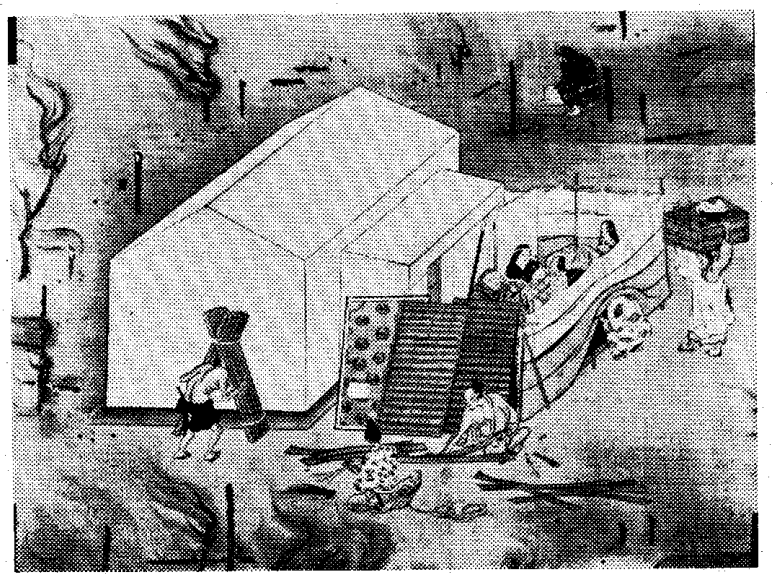

第 2 図 春日験記絵巻中に党る土倉

序に少しく他の防火構造を調べてみよう。先ず考えら れるのは、現今一般に都会と農村とを問わず広く流布さ れている所謂土蔵にして、この起源が何処まで遡り得る かが問題である。恐らくこれは民家等にみられる土壁類 から発详したものと考学られるが、有名な春日験記絵巻 中に、立派な土蔵が描かれて、しかもこれが完全に防火 の役割を果して、類焼を免れ、焼土中に悠然と算立する ことは、衆知の如く第2図にみられる通りであり、従つ て鎌倉時代には少くとも所謂土蔵の方は已に完成してい たことが分る。これを文献上に求めてる、明月記、嘉保 2 年 10 月 6 日 (1226) 条中以、

去比雨降夜、窃盗穿通具卿之土合。

とみえ、钬盗が大納言源通具卿の邸内にある土倉に穴を 開けて、収蔵せる我鳥眼、即ち金銭 300 貫、沙金一盇、濃 州の桑絲 60 正、鋤、鉄等を盗去つたといろ。この通具 邸は、前年たる嘉淥 1 年 12 月 26 日に羅災しているか ら、当時は邸内の他の諸建築は䍜災して失われていた筈 であり、従つて邸内には、焼跡にこの土倉だけが焼残つ ていたのであるう。即らこの土倉こそ完全に防火の役割 を果したことが立証された理であり、恐らくは春日験記 中にみえる夫と同種類のものであつたと思われる。䡒残 
つたばかりに、盗人の犯す所となつたわけだが、盗むと しても、穿つたとあるのは、厚い土壁に穴をあけたこと を意味するすのであろう。この種の土蔵が平安時代迄遡 つて存在したであろうことは当然考兄られ、延喜式、主 税（下）に、法倉、瓦倉飞次いで「土倉若干宇」と明記 されるほか、

五間ばかりなるひはだ屋のしると、土屋ぐらなとあれ ぞ (大和物語下)

そみえる「土屋ぐら」や、古今著聞集 (一、神祇) 中に

当社の土屋を造進したりけり、(当社とは賀茂のこと) などとみえる土屋などす、多分同種類の夫であつたと思 われる。そして、この土倉が鎌倉時代になると市街地化 住む富商等により自然多く用いられる様になつたものと み光、このととは明月記、文暦 1 年 8 月 (1234) 条中に より立証される。即ち 8 月 3 日、暁鐘の程、南方飞当つ て火災があり、七条辺の東西 3 町許焼失した由を述へ、 続いて 5 日条中に、一昨日の火焱の詳報として、鳥丸 西、油小路東、七条坊門南、入条坊門北の一帯が地を払 つて楛亡した由を述べたあと、

土倉不知員数、商賈充満、海内之財貨只在其所云々。 と記される。即ち当時七条坊門から、八条坊門加けて は、富商が充満していたといい、土倉が無数にあつたと いうの怯、焼土に土倉だけが無数に焼残つたという意味 であろろ。余談乍ら䍜災した翌日から早速復興の造作を 始めたとあるが、商人魂の旺盛なととは、吞気だつたと 思われる鎌倉時代に於てさ兄現在と変らぬこと飞驚かさ れるし、続いて焼跡での様子を記して、互に幔を引廻し たというのは、そのまま前揭の春日験記中の夫と一致し ている。文智 1 年の火炎以後、間すない建長 7 年(1255) 飞恃鎌倉無尽銭、即ち質屋の公令となり、質屋の性格上 土倉を必要とするに至り、かくて次第に次の室町時代に かけて、土倉は質屋の別称となると至つた。

以上述べた所を要約すると、平安、鐮倉時代に打ける 邸宅乃至官庁中には、書籍文書等を収蔵して挌くべき場 所として、文倉を設けたが、文倉は時に文殿、文庫、書 庫、書倉などとも呼ばれ、共に大体同一性實のるのであ つた。著名なるので、平安京内に括けるものでは、貞観
17 年に罹炎した冷然院、仁平 3 年に炎上せる大江家累 代の江家交庫、嘉祿 2 年䍜災の太政官文庫、鏮倉幕府関 係では名越交庫、金沢文庫等が挙げられるが、これら諸 文庫は金沢文庫以外は尽く稚災している。金沢文庫が羅 苂を免れたのは地形上防火に注意した為と思われるが、 これを更に進めて、建物自体をる防火構造としたのが、 左大臣頼長の文倉であり、その内容が詳細に知られる点 飞於て貴重な資料である。猶最後に防火建築の一環とし て、土倉の起源にるまれて捂いた ${ }^{(7)}$ 。

[註]

（1）殿にも文殿あけさせ給ひて、まだひらかぬみづ しぞもの、めづらしき古集のゆ急なから奴、すと しえりいでさせ給ひて（源氏、賢木)。

ろしとらの町の西対、文殿にてあるを、ことかた へ移してと拓济す（源氏、玉葛）。

遍照寺の僧都は、交殿などにうちつれたる。(紫式 部日記)。

うまばの御殿、文殿などまでみなさまさまにしる つつ(栄花物語、初花)。

（2）就中樋口町尻江家文庫、不能開闧、萬巻都書、 片時為灰了、是朝之遗恨、人之愁悶也（兵範記、 化平 3.4.15)。

（3）江家十代之書 倉 同 遭此殊桶口南、西洞院東、号千草 （本朝世紀、仁平 3.4.15)。

（4）去夜太政官庁西文庫焼亡云夕、社䅡㙎亡、悲而 有余（明月記、喜禄 2.8.27）。

今夜梅小路 堀河故宗隆卿文庫焼亡、和漢文書多為 灰橴（百錬抄、嘉禄 2.8.18）。

（5）正月十九日、大炊高倉亭乾角立文倉、今日午刻 居礎、件倉成無火難之構、暦権博士憲栄鞠日時、 佐渡前更伊俊献指図。廿七日、今日辰刻、文倉棟 上 (台記)。

（6）天養二年四月二日、自正月所始之文倉造了、今 日置文書、依吉時用午刻、余着冠直衣、取春秋緯 楆、先入置陽棚東棚五重、解之陽、蔵人式部丞藤成佐 着束带、取易詩等 緯、及河 渠書齄、復入置陰棚 西棚六重、鲫之陰 (台記)。

（7）本稿は曾て昭和 15 年 4 月飞書いたるのだが、 戦災で原稿を失つてしいい、その後極めて簡単に 防火構造の一部の紹介をみた以外飞、未だ詳述さ れていない様なので、19 年後の今日、改めて発表 した次第である。 